\title{
Is Bertrand de Jouvenel only a Liberal Philosopher? The Relations between His Political Thought with the Twentieth Century Sociological Thought
}

\author{
Gabriele Ciampini
}

\begin{abstract}
My paper is dedicated to Bertrand de Jouvenel's political thought. My present work frames his thoughts into new theoretical paradigms.If we look at the critical literature on Jouvenel, we realize that this thinker is commonly regarded by his interpreters as a Liberal philosopher.This is the case for instance of Olivier Dard who, in his work Bertrand de Jouvenel (2008), emphasizes the similarities between Jouvenel's thought and that of Friedrich von Hayek. Jouvenel, in fact, was a member of the Mont Pelerin Society, an international organization advocating for pro-market policies. This view has certainly some truth, since in his major works, $D u$ Pouvoir (1945)and De la Souveraineté (1955)he displays his conception of history saying that it is part of the anti-statist tradition. My essay aims at integrating this approach, illustrating the connections between Jouvenel and some sociological thoughts.
\end{abstract}

Index Terms-Democracy, history of sociological thought, jouvenel, kornhauser, lasswell, pluralism, political theory.

\section{INTRODUCTION}

My paper is dedicated to Bertrand de Jouvenel's political thought. My present work frames his thoughts into new theoretical paradigms.

If we look at the critical literature on Jouvenel, we realize that this thinker is commonly regarded by his interpreters as a Liberal philosopher.

This is the case for instance of Olivier Dard who, in his work Bertrand de Jouvenel [1], emphasizes the similarities between Jouvenel's thought and that of Friedrich von Hayek.

Another interpreter, Daniel J. Mahoney, has written: "In the years between 1945 and 1968, Jouvenel produced an impressive body of works belonging to the tradition known as conservative liberalism. These writings explored the growth of state power in modern times, the difficult but necessary task of articulating a conception of the common good appropriate to a dynamic, 'progressive' society, and the challenge of formulating a political science that could reconcile tradition and change while preserving the freedom and dignity of the individual' [2].

This view has certainly some truth, since in his major works, Du Pouvoir [3] and De la Souveraineté [4] he displays his conception of history saying that it is part of the anti-statist tradition. Jouvenel, all along his various works includes many elements belonging to the philosophy developed by Alexis de Tocqueville. This paper aims at integrating this approach, illustrating the influence on

Manuscript received April 17, 2013; revised June 21, 2013. The author would like to thank Jessica Mourtont for correcting his paper.

Gabriele Ciampini is with the University of Florence, Italy (e-mail: gabriele.ciampini@virgilio.it).
Jouvenel by the tradition of the "élites theory" and by some exponent of contemporary American sociology, as William Kornhauser and Harold D. Lasswell.

\section{JOUVENEL AND THE ÉLITE THEORY}

It's possible to understand that the concept of "élite" is very important for Jouvenel's political theory: in the Middle Ages when sovereignty was exercised by a small group of people, while in modern times Power is exercised in the name of the whole society.

At this point Jouvenel integrates sociological elements into his philosophy: he develops a theory on contemporary democracy very close to those developed by theorists such as Gaetano Mosca [5], Vilfredo Pareto [6] and Robert Michels [7].

Jouvenel firmly denounces the fact that in modern democracies, Parliament does not perform the task of representing the multiple ideological positions and the plurality of interests typical of a complex society: his task seems to preserve Power and increase strength. Parliament is like a tool in favor of the ruling oligarchy.

Jouvenel underlines two aspects of Power in democratic regimes: first, it is controlled by Parliament, which in turn is operated by a committee within it. This means that no Member of Parliament has substantial margins of autonomy, because they have to follow the decisions taken by an even more restricted group of individuals. The second aspect deals with the Members of Parliament's social background: over time, they tend to come from lower classes.

Regarding the latter question, Jouvenel says that the conviction that Parliament is an expression of general will, is due to a 'daring fiction': Parliament has begun to consider the People (with autonomous political subjectivity), in assembly. Then, the Executive, once given the Parliament's legitimacy, is called 'government of the People'.

Francesco Rinaldini affirms that "When the French Revolution proclaimed the principle of popular sovereignty, it came to be delegated to the National Asssembly and the king. Once the monarchy was abolished, the new parliament had to take a radically different look from what had existed till then. It didn't represent special interests found in society but it replaced the monarchic representation as an embodiement of the totality of the nation. It tends to be, not an assembly of delegates but the people itself gathered in assembly, in such a way that the decision is to be formed, as Sieyes required in the end of September, 1789, according to the modality in which the general will of the people is shaped once gathered in assembly, as described by 
Rousseau in the Social Contract" (my translation) [8].

According to this approach, Power would gain back its own legitimacy. The point is not that Power would derive from the bottom, just as hoped by those who consider the French Revolution and the advent of /the people/the plebs/ to power as a positive aspect in itself, but, something even more important, the head of the central government should be accountable of his acts to the politicians who put him into power. As in feudal times, in order to keep social and political cohesion, it is the respect of pluralism inherent to society that must be respected.

The idea of parliamentary sovereignty has been modified in favor of the new political class. Jouvenel also describes the intermediate step which triggered this change in European political culture: In the Nineteenth Century, Members of Parliament were elected democratically, but all of them came from high social classes. They had received an excellent education; they knew the complexity of society and were not willing to give in to populism. These politicians played a role similar to as the aristocracy. Considering this,

Jouvenelis not surprise by the absence of genuine popular participation in the democratic process. Every government is run by an élite; but if it prevents the advance of Power while respecting all the political actors, then the élite shall perform its political duties.

Jouvenel examines the mechanisms selecting the political class, by paying attention to the role of political parties in the formation of the ruling class in the Twentieth Century. The parties are no longer the tools of representation, but they have increasingly become distant from the electoral body, growing into oligarchies. If Parliament had the whole Power, the representatives would not feel so compelled to defend everybody's interests in society, but to organize themselves into groups separated from each other without the slightest desire to work together to find solutions that could comply with the general interest. Parliamentary debates, then, are no longer characterized by pragmatism and the desire to solve real problems; it has become a purely ideological confrontation between groups fighting for Power

Furthermore, electing MPs on the basis of abstract ideals, the voter would have been freer, more able to influence the decision-making process. Jouvenel strongly criticizes this view, stating that if the voter relies on abstract values without taking into account its own interests, it allows the political class to emancipate itself from the will coming from the bottom of society.

In fact, Jouvenel notes that there has been, in the Twentieth century, a curious reversal of the parts:

it seems that the voters do not choose the politicians but they actually impose themselves on voters. Appealing to political ideologies, the leadership of a party can impose on candidates of their political orientation candidates who do not deserve to be elected: "Thanks to the prestige of its leaders and the popularity of its principles, the group makes candidates it chose win not because of their personal credit but for the obedience they promise; they will be all the more loyal because they will be unable to have a carrier of their own.

In Du Pouvoir the topic of powerful party organizations capable of impacting on the choice of citizens is openly tackled. This happens not only because of the amount of money a party can display for a campaign, or because it is deeply rooted into society; it happens because the arguments given to obtain the consensus are not based on a rational analysis of the situation, but they appeal to the voters's emotions. With this, Jouvenel highlights that the electoral success of parties are inversely proportional to their merits: they can be voted for the ideology they defend and not for the problems they solve, for their ability to entertain relations of patronage with individuals who then reward them by giving them their vote. Moreover, elections based on partisanship create a sense of belonging which can become a real camaraderie.

Here Jouvenel's analysis is very similar to that developed by Gaetano Mosca. The founder of the theory of elites asserts, as he will later do with a deeper analysisMichels, that the organization of political parties leads these organizations to be ruled by an oligarchy. The theory of elites is for Mosca suitable to describe the reality as each company is composed of an organized minority imposing itself on the disorganized majority. "Among the constant facts and tendencies that are to be found in all political organisms, one is so obvious that it is apparent to the most casual eye. In all societies - from societies that are very meagerly developed and have barely attained the dawning of civilization, down to the most advanced and powerful societies - two classes of people appear - a class that rules and a class that is ruled. The first class, always the less numerous, performs all political functions, monopolizes power and enjoys the advantages that power brings, whereas the second, the more numerous class, is derected and controlled by the first, in a manner that is now more or less legal, now more or less arbitrary and violent, and supplies the first, in appearance at least, with material means of subsistence and with the instrumentalities that are essential to the vitality of the political organism" [9]. In fact, Moscow emphasizes the psychological mechanism with which few individuals can coalesce in order to form a true social body. He describes the process by which you come to the cohesion of a particular political organization, due to the affinity of interests. Each member of the oligarchy feels that his interests are similar to those of the group. Mutual cooperation is therefore spontaneous. This applies to all social organizations, including therefore the parties.

Jouvenel realizes that it is impossible to return to premodern era. Jouvenel does not categorically rejects the collective political participation, but he asserts that true democracy is only possible in small communities. Administrators should be known by all citizens, so that they actually know the way in which public affairs are managed. Citizens should elect the municipal administrators. The letters should elect county administrators. They would have to elect the regional administrators. We come to the appointment of members of parliament by the regional administrators. According to Jouvenel, such an institutional arrangement would be more balanced: he wishes to avoid the phenomenon of populism, one of the negative characteristics of contemporary democracies.

Each administrator, including Parliament, is appointed and supervised by a small number of individuals. In such a way, it should create a system of control starting from the 
citizens and involving all levels of the administration. In this context, no politician should claim the right to speak in the name of the people, understood as a shapeless mass/group deprived from any subjective interests Jouvenel's aim is to try to create/develop an institutional model that could, through the presence of modern intermediate bodies, curb the growth of Power. The problem is that his approach is not deprived of flaws: at each level of representation a fraction of the requests coming from the bottom is lost.

\section{JOUVENEL AND W. KORNHAUSER}

Jouvenel wants to illustrate the historical genesis by which the Power of State (capital P is used to distinguish State power from other powers found in any human society) gradually acquires more importance: the author has described the road traveled by Power from the Middle Ages to the present, trying to demonstrate how in feudal times it was kept under control by intermediate bodies, represented by the aristocracy.

Jouvenel says that Power is structurally characterized by a tendency to acquire an increasing number of prerogatives. In this way, the totalitarian systems of the Twentieth century do not represent 'mishaps' but a foreseeable pattern of progressive growth of government in modern societies. This growth began centuries ago, when the sovereigns began to fight against the privileges of the aristocracy which threatened to control the central Power.

For Jouvenel, the political ideal is determined by the presence of aristocratic elements which put an end to State Power.

With the French Revolution, everything changed. His staunchest defenders, the Jacobins, called for the direct intervention of the People in political life. After the French Revolution, as followers of Robespierre, they were not only willing to respect the popular will, but also wanted to punish those who did not comply with the government's decisions, supporting the purge of Terror. Their goal was the complete realization of the democratic ideal. According to this view, the People was seen as the source of political sovereignty, as the holder of a non debatable opinion. For Jouvenel, this conception legitimates an abnormal extension of Power.

According to him, the concept of 'totalitarian democracy' [10] is absolutely central to understand the politics of the Twentieth century. The guilds of the Middle-Ages represented the various parts of society. For example, each guild had its own economic representatives. The king was therefore the one who had the task of mediating between the various social issues to develop common solutions. Only then, taking into account the profound heterogeneity of the social body, the 'common good' could be reached. The characteristics of pre-modern societies were that no social group wanted to be considered as the spokesman for the whole society. With the coming of democracy as we know it today, sovereignty became the space of a selected group of individuals who claimed to administer in the name of the People, seen as a homogeneous entity.

Society consists of various elements such as industry, associations, lobbies and moral or even spiritual authorities, whose role is to counter-balance the social organization. From this point of view, the freedom of association takes a central role.

Pluralism, however, is a changeable concept. It can be considered as something different according to the various political and cultural fields. In fact, Norberto Bobbio [11] distinguishes three different conceptions of pluralism: Liberal, Socialist and Catholic. The first two are part of the 'modern pluralism', because these ideologies emphasize the spontaneity of gathering. On the contrary, the Catholic's point of view focuses on the forms of community such as the family and the Church. The Catholic pluralism fights against the centralized State to resurrect the old state of classes and orders that the French Revolution had given up for dead and goes back, to show a pattern of intermediate users, to the medieval guilds.

At this point, it is interesting to highlight the similarities between this part of Jouvenel's political theory, with William Kornhauser's sociological thought, author of The Political of Mass Society [12]. Quoting Tocqueville's political theory on democracy [13], Kornhauser emphasizes that the absence of a developed network of intermediate bodies facilitates the isolation of the individuals and prevents their ability to connect with each others, thus leaving the free hand to the State which is characterized by a systematic interventionism. As affirmed by Luciano Pellicani, "by this way, citizens can take part in political life only through state-dependent structures, or other institutions with limited independence. These structures become more and more centralized and bureaucratic, and they contribute to the creation of 'lonely crowds'. In addition, in a society where the intermediate powers are absent or weak, the presence of mass media favors the atomization of society" (my translation) [14].

Ultimately, Kornhauser stated that mass society should be seen as a social apathy. It is the result of the disintegration of traditional community levels that characterized not fully industrialized societies. These type of societies aimed at protecting the individual within a familiar socio-cultural dimension.

Contemporary times show an impersonal uniformity of lifestyles and a general flattening of the various cultures and traditions within societies. "In this way, the boundaries separating the élite from the masses become more and more flexible. Indeed, it reveals the élite's tendency to fall, to become masses themselves. Moreover, it prevents the isolation of individuals and enable a comprehensive and composite participation in the political and cultural life, not necessarily mediated by the State and its bureaucratic structures. When society presents itself as a system of checks and balances, it can be self-regulated. Social actors can escape the manipulation of mass-media and demagogues and finally act as citizens aware of their rights, once provided with the tools required to exercise them" (my translation) [14].

\section{JOUVENEL AND H. LASSWELL}

We can notice that Jouvenel's philosophical inquiry and sociological research go together. On this topic, Jouvenel's political theory of Power tends to be close to that developed by Harold Lasswell, one of the most important American sociologists. 
Jouvenel didn't actually limit himself to the mere description of Power growth from a historical perspective; In The Pure Theory of Politics [15], he has developed the 'law of conservative exclusion': given that politics is based on the use of Power, which is the dialectic between provocation and response. Incitement is defined as the ability to push person A to person B to perform the action $H$. The instigation of an action consists in an exhortation, an order, but also in a request. Political actions start by the instigation. Authority is that which makes human communities. It doesn't consist in the force, but in the influence which a person has on the members of a social group.

Jouvenel tries to develop a political and sociological theory by an attempt at identifying the continuous dynamics of the formation of power. He says that the real leader of a community is the one who is able to convey to society stability and order. The political leader is then rex or a political figure, in the same way medieval kings guaranteed the cohesion of the community, in addition, Jouvenel states that there is another concept to understand the formation of power, that of $d u x$. This concept denotes the ability of the leader to set in motion certain political processes, making sure that other members of the community follow him. As Mario Stoppino says, the $d u x$ is "a principle of innovation and change, at the center of which is the political entrepreneur, a man with a strong personality who, looking for a goal to be pursued, builds and grows by himself, with his efforts, day after day, his own path" [16].

The concept of $d u x$ therefore refers to a dynamic principle, while rex refers to a static principle. According to Jouvenel, the political leader has in itself both characteristics: he is able to convince society to follow him, but is also able to ensure stability and order into the community.

The dux is the leader, the innovator, the one who permits collective action. He is the fighter who wins a war or helps getting out of a crisis. His activity is necessarily temporary. He represents a dynamic policy.

From this view, we can deduce that Jouvenel does not agree with the contractualist vision of the birth of society. Society doesn't come thanks to an agreement among citizens. Besides this, the idea that it arises from a violent confrontation is discarded. According to Jouvenel, society is born from the capacity of a political actor able to drag the members of the community. This kind of authority is at the basis of the state constitution. Jouvenel tends to reject the hypothesis that society is the result of a spontaneous consensus to be gathered together. Similarly, he rejects the idea that the state would simply be the result of violence, of a forced domination. For Jouvenel, the social group is based on the input of an individual who requests his training. These would be the auctor, in other words, the "efficient cause of voluntary meetings", the one who leads others, by a consensus, to join the group.

The political action of the $d u x$, however, can only be temporary. The political system cannot be continuously subjected to movement. There must be an institutionalization of the social group. It is at this point that the figure of the king emerges. The form of authority called rex appears so universally necessary to ensure the trust and overcome disagreements: we believe that it is the original source of sovereignty. The rex puts borders, guarantees the obligations, resolve conflicts.

The rex ensures that the socio-political framework is stable. Stability is the necessary condition to guarantee freedom and security. The rex, as well as act as a guarantor for the commitments made, performs the role of judge in any dispute.

The figure of the rex is certainly ideal and desirable, but it is for Jouvenel an essential element because any sociopolitical context has to be fair and stable. The figure of the rex faithfully reproduces the common image of the medieval ruler, authoritative and balanced.

According to Jouvenel, the central point of the matter is once again the concept of authority, the more influence person A has on person B, the lower autonomy he has: "I want to use the word 'authority' to denote the position in which 'A' finds himself in relation to 'Bs' who 'look up to him', 'lend him their ears', have a strong propensity to comply with his bidding" [17].

Lasswell has developed a theory of power very close to that of Jouvenel. In Power and Society [18] he stated that the influence of one individual on another is determined by the possession of valuesdeemed important by the community: moral reputation, success, wealth, and so on. Social consideration is directly proportional to the presence of these elements.

'Power' is a particular type of influence. It is a condition in which an actor obtains a desired behavior from another by the use of constraints or remuneration.

From this assumption, Lasswell puts at the center of his sociology, not so much the amount of items with which they could earn social prestige, but the actual ability to make decisions. These decisions however, are not only taken by rulers, but also by anyone else who has the power to influence others (as an entrepreneur or a member of the Church). They are part of both the political élite and the Government. They actually hold to a certain extent the values (such as wealth and religious authority) of the ruling class.

From here it is possible to highlight the similarities and differences between Jouvenel's theory and Lasswell's, and try to investigate particular aspects, starting from the interpretation offered by Mario Stoppino, who states that "On the one hand, Lasswell uses the concept of power to define, in a direct policy and on the other, Jouvenel uses the notion of power (of instigation and response) to find the simplest elements and "nuclear" policy. For Lasswell, where there is power there, on that account without any qualification, politics. For Jouvenel where there is no provocation-response - we might say - an embryo of politics. Lasswell says that entire policy, in all its complexity, is purely and simply the exercise of power; for Jouvenel policy, in its fullness and complexity, but a development or as he writes - a "bias", a "systematic" reports of incitement and response"(my translation) [19].

\section{CONCLUSION}

The aim of this paper is to shade a new light on Bertrand de Jouvenel. Through the analysis of his thought, taking into account the theory of elites and the work done by some 
members of the contemporary American sociology on the theory of elites, I have been able to develop a program whose aim was to highlight the relationship between the thought of Jouvenel and some of the most important exponents of the Twentieth century's sociologies. Jouvenel starts from mainly philosophical positions contained in DuPouvoir and in De la Souveraineté to arrive to an analysis much closer to modern political science with The Pure Theory of Politics. In all these works, Jouvenel intends to analyze the dynamics of power, using various approaches. In Du Pouvoir the approach is historical: Jouvenel aims at showing how the political power grows out of proportion according to the different eras. In De la SouveraintéJouvenel analyzes the organization of society through a more philosophical approach, in which he displays a reflection on the concept of common good. Finally, in The Pure Theory of Politics, politics is examined possibly with a more analytical bias, its core being the ability to influence among the various actors in society.

These different approaches are not mutually disjoint, they all have a common matrix or stand as an attempt at shaping a system of thought designed to warn against the illiberal tendencies of the state.

\section{REFERENCES}

[1] O. Dard, Bertrand de Jouvenel, Paris: Perrin, 2008.

[2] D. Mahoney, Bertrand de Jouvenel: Conservative Liberal and the Illusion of Modernity, Wilmington, Delaware: ISI Books, pp. 5, 2005.

[3] B. D. Jouvenel, Du Pouvoir, Paris: Librerie Hachette, 1945.

[4] B. D. Jouvenel, De la souveraineté, Paris: Génin, 1955.

[5] G. Mosca, Elementi di scienza politica, Roma: Fratelli Bocca, 1896

[6] V. Pareto, Trattato di sociologia generale, Firenze: Barbera, 1923.

[7] R. Michels, Zur Soziologie des Parteiwesens in der modernen Demokratie, Leipzig, Dr. Werner Klinkhard, 1911.
[8] F. Rinaldini, Bertrand de Jouvenel. Introduzione alla teoria politica, Napoli: Edizioni Scientifiche Italiane, 1997, pp. 39 (in italian).

[9] G. Mosca, The Ruling Class, New York: MacGraw-Hill Book Company, 1939, pp. 50.

[10] L. Talmon, The Origins of Totalitarian Democracy, London: Secker and Warburg, 1952.

[11] N. Bobbio, Teoria generale della politica, Torino: Einaudi, 1999.

[12] W. Kornhauser, Politics and Mass Society, Glencoe: Free Press, 1959.

[13] W. Kornhauser, Politics and Mass Society, Glencoe: Free Press, 1959, pp. 133-134.

[14] L. Pellicani, "Società di massa," in Enciclopedia delle Scienze Sociali, Roma: Istituto Italiano dell'Enciclopedia, 1998.

[15] B. D. Jouvenel, The Pure Theory of Politics, New Haven: Yale University Press, 1963.

[16] M. Stoppino, Introduzione at La teoriapuradellapolitica the Pure Theory of Politics), Milano: Giuffré, 1997, pp. 40.

[17] B. D. Jouvenel, The Pure Theory of Politics, New Haven: Yale University Press, 1963, pp. 100.

[18] H. Lasswell and A. Kaplan, Power and Society, New Heaven: Yale University Press, 1950.

[19] M. Stoppino, Potere ed élites politiche, Milano: Giuffré, 2000, pp. $165-166$.

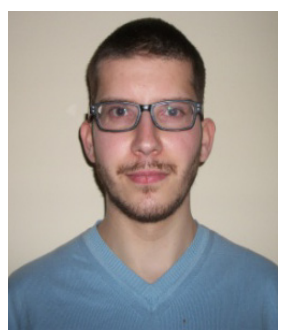

Gabriele Ciampini is a $\mathrm{PhD}$ student at the University of Florence. His dissertation title is The Critique to Democracy of Bertrand de Jouvenel. An Inquiry between Philosophy and Sociology. He studied Political Philosophy at the University of Pisa. He has been visiting student at theUniversitéLibre de Bruxelles. He has participated in several international conferences in Belgium, Canada, China and France. During the first year of his Ph.D., he has organized a co-tutorship with the ParisSorbonne University. He is currently a member of an italian research project titled Il "governo del popolo": partecipazione, consenso, esclusione nella costruzione delle democrazie contemporanee (1815-1914). His research focuses on the figure of Bertrand de Jouvenel, the theory of democracy and the relationship between philosophy and political science. 